\title{
GMR
}

\section{Genetic diversity and structure in natural populations of Maytenus truncata Reiss, 1861 , a medicinal plant vulnerable to extractivism in Bahia State, Brazil}

\author{
R.R. Simplicio', A.M. Waldschmidtt, M.B. Amorim ${ }^{1}$, B.S. Almeida ${ }^{1}$ and \\ D.G. Pereira ${ }^{2}$ \\ ${ }^{1}$ Departamento de Ciências Biológicas, \\ Universidade Estadual de Sudoeste da Bahia, Jequié, BA, Brasil \\ ${ }^{2}$ Departamento de Química e Exatas, \\ Universidade Estadual de Sudoeste da Bahia, Jequié, BA, Brasil \\ Corresponding author: R.R. Simplicio \\ E-mail: renatasimpliciouesb@gmail.com
}

Genet. Mol. Res. 14 (4): 18241-18248 (2015)

Received August 10, 2015

Accepted October 26, 2015

Published December 23, 2015

DOI http://dx.doi.org/10.4238/2015.December.23.11

ABSTRACT. Maytenus truncata (Celastraceae) is a plant species widely used in the treatment of ulcers and tumors. Despite the intensive harvest of native specimens in the State of Bahia, northeastern Brazil, there is no information about the genetic variability or structure of this species. Therefore, the goal of this study was to estimate the genetic diversity and population structure of $M$. truncata based on inter simple sequence repeat (ISSR) molecular markers. The samples comprised specimens from Jequié, Contendas do Sincorá, Boa Nova, and Boa Vista do Tupim in the State of Bahia. After selection of eight ISSR primers, the percentage of polymorphic loci was equal to $96.2 \%$ and genetic diversity was 0.3581 . The Mantel test revealed positive correlation among genetic and geographic distances $(r=0.5462)$, but it was not significant $(r \geq$ $0, P=0.8365$ ). Even though AMOVA revealed that most variation was 
found within populations (68\%), a high structuring was detected among them $\left(\Phi_{\mathrm{ST}}=0.31, \mathrm{P}<0.001\right)$. Both UPGMA and Bayesian analyses indicated that gene flow was higher between Jequié and Contendas do Sincorá, whereas samples from Boa Nova and Boa Vista do Tupim were more isolated. This result is likely because of the population decrease and restriction to gene flow associated with intensive extractivism of populations of this species.

Key words: Genetic variability; ISSR; Harvesting; Conservation

\section{INTRODUCTION}

Plant species of the genus Maytenus (family Celastraceae), known in Brazil as "espinheirasanta”, are widely used in popular medicine (Silva et al., 2008). Maytenus truncata, endemic to Bahia, northeastern Brazil, is the fourth most commercialized native species in Brazil because of its pharmaceutical properties (Steenbock and Reis, 2004). According to Fonseca (2007), this species is usually found in areas of predominance of caatinga. This plant reaches $2 \mathrm{~m}$ in height with a branched trunk and coriaceous leaves with a truncate base and dentate margins. In popular culture, both fresh or dry stems and leaves are used in the preparation of teas or infusions for medical treatment (Silva et al., 2008).

According to Negri et al. (2009), the anti-inflammatory, cicatrizing, and antiulcerogenic properties recognized for this species are related to the presence of flavonoids and tannin groups. Triterpene derivatives have also been isolated from species of the Maytenus genus. These antimitotic compounds are highly active against several tumor cell lines (Morita et al., 2008; Almeida et al., 2010; Momtaz et al., 2013). Triterpene derivatives also exhibit cytotoxic activity against cancer cells through butulínico acid derivatives (Martucciello et al., 2010) and antibacterial properties against Staphylococcus aureus, using derivatives from the class of zeylasterone (Leon et al., 2010). Forest fragmentation caused by the increased demands of popular pharmaceutical products might jeopardize native plant species since reduction and/ or isolation of populations will eventually determine losses of genetic diversity and changes in the genetic pool (Fonseca et al., 2007; Wu et al., 2014). With the advances of molecular biology and techniques of recombinant DNA based on PCR (polymerase chain reaction) and automatic sequencing, molecular markers could be developed and used to identify genetic resources. These data are helpful in establishing proper strategies of management for both conservation and genetic improvement plans (Faleiro, 2007). Amongst the molecular markers available to evaluate population diversity, Inter Simple Sequence Repeat (ISSR) markers stand out for disregarding any previous knowledge about the genome of target species (Zietkiewicz et al., 1994). Based on utilization of a single primer (16-20 bp) flanking microsatellite regions, this method allows reliable results and detection of polymorphisms, even though it fails to detect heterozygous individuals (Liu and Wendel, 2001).

Since Maytenus truncata has been intensively exploited and no genetic studies have been performed on this species, the present work focused on assessing the genetic diversity of $M$. truncata by ISSR markers. The goal was to verify the influence of environmental degradation and exploitation on population structure with insight to possible species conservation practices. 


\section{MATERIAL AND METHODS}

\section{Biological material and DNA extraction}

Young leaves of 71 individuals of $M$. truncata were collected in four locations in the state of Bahia, northeastern Brazil. Because of intensive extractivism of this species, only 11 samples were collected in Boa Vista do Tupim (Table 1; Figure 1). The extraction of total DNA was performed according to Silva et al. (2008) and quality and integrity of DNA samples were verified by using a spectrophotometer L-Quant (Loccus ${ }^{\odot}$ ).

Table 1. Collection sites, coordinates, altitude, and number of individuals $(\mathrm{N})$ sampled per population in the State of Bahia with their respective expected $\left(H_{E}\right)$ and observed $\left(H_{0}\right)$ heterozygosity values.

\begin{tabular}{|c|c|c|c|c|c|c|}
\hline Locality & Latitude & Longitude & Altitude $(\mathrm{m})$ & $\mathrm{N}^{*}$ & $H_{\mathrm{E}}^{* *}$ & $H_{\mathrm{o}}^{* * *}$ \\
\hline Jequié & -13.851 & -40.0812 & 218 & 20 & 0.2770 & 0.2815 \\
\hline Contendas do Sincorá & -13.7621 & -41.0426 & 292 & 20 & 0.2468 & 0.2580 \\
\hline Boa Nova & -14.3542 & -40.2129 & 748 & 20 & 0.3113 & 0.3325 \\
\hline Boa Vista do Tupim & -12.6625 & -40.6054 & 310 & 11 & 0.2247 & 0.2468 \\
\hline Total & & & & 71 & 0.3581 & 0.3518 \\
\hline
\end{tabular}

${ }^{*} \mathrm{~N}=$ number of samples; ${ }^{* *} H_{\mathrm{E}}=$ expected heterozygosity; ${ }^{* \star *} H_{\mathrm{O}}=$ observed heterozygosity.

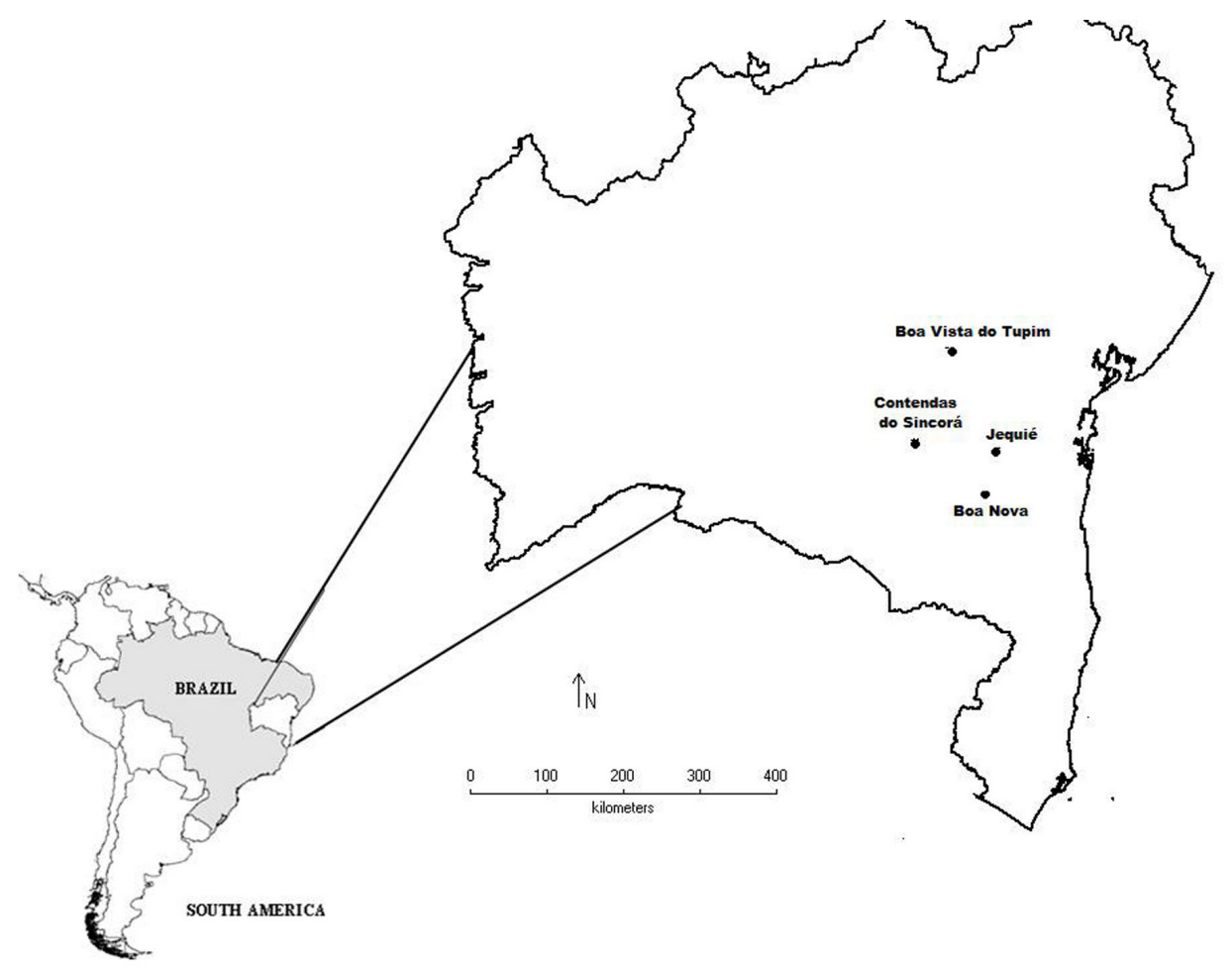

Figure 1. Location of collection sites of Maytenus truncata in the State of Bahia. 


\section{PCRs and electrophoresis}

Thirty-eight ISSR primers (Wmed Ltd., Southall, Middlesex, United Kingdom) were tested for amplification of DNA as described by Zietkiewicz et al. (1994). Based on amplification profiles, eight primers were then selected since they proved to generate polymorphic patterns and yielded high-resolution and reproducible bands (Table 2). The PCR mix comprised $2.5 \mu \mathrm{L} 10 \mathrm{X}$ buffer (BioTools, Valle de Tobalina, Madrid, Spain), $25 \mu \mathrm{M}$ dNTP, 0.5 U DNA polymerase (Biotools), 5 $\mu \mathrm{M}$ ISSR primer, $12.5 \mathrm{ng} / \mu \mathrm{L}$ template DNA and ultrapure water to a final volume of $25 \mu \mathrm{L}$. The amplification conditions were: an initial denaturation step at $94^{\circ} \mathrm{C}$ for $3 \mathrm{~min}$ followed by 39 cycles at $92^{\circ} \mathrm{C}$ for $1 \mathrm{~min}, 53^{\circ} \mathrm{C}$ for $2 \mathrm{~min}$ and $72^{\circ} \mathrm{C}$ for $2 \mathrm{~min}$, plus a final extension step at $72^{\circ} \mathrm{C}$ for $7 \mathrm{~min}$. All PCRs were carried out in an Eppendorf $A G$ thermocycler.

Amplified fragments were separated by electrophoresis on $1.2 \%$ agarose gel immersed in 1X TBE buffer (90 mM Tris-Borate and $1 \mathrm{mM}$ EDTA), visualized under UV light and photodocumented using L-PIX system (Loccus, Cotia, São Paulo, Brasil). The size of fragments was estimated by comparing them to a 100 bp ladder (Invitrogen, São Paulo, Brasil).

\section{Statistical analyses}

These data were used to build a binary matrix to estimate the percentage of polymorphic loci $(P)$, expected heterozygosity $\left(H_{\mathrm{E}}\right)$ and observed heterozygosity $\left(H_{\mathrm{O}}\right)$ using the software TFPGA version 1.3 (Miller, 1997). The analysis of molecular variance (AMOVA) was performed within and among collection sites and a fixation index $\left(\Phi_{\mathrm{ST}}\right)$ was established with the software Arlequin version 3.1 (Excoffier et al., 2007). A dendrogram of genetic similarity based on UPGMA (unweighted pair group method with arithmetic mean) using Nei's coefficient (1973) was built using the software TFPGA version 1.3 (Miller, 1997) with 1000 permutations to test the clustering consistency.

Bayesian analysis was performed with the software Structure version 2.2.3 (Falush et al., 2007). The number of populations $K$ was adjusted to range from 1 to 5 , with 20 independent interactions, each using burn-in and MCMC (Monte Carlo Markov Chain) of $10^{10}$ iterations. After adjusting the program to dominant molecular markers, the admixture model was determined and the correlation between allele frequencies and populations was estimated. The structure results were analyzed via Structure Harvester Web version 0.6.9 as suggested by Evanno et al. (2005) to determine the most likely number of groups. Significant relationships between genetic and geographic correlation among pairs of populations were estimated using the Mantel test as implemented in the Isolation By Distance Web Service v. 3.23 (10,000 randomizations) (Jensen et al., 2005). The geographic distances were assessed by Geographic Distance Matrix Generator software v. 1.2.3 (Ersts, 2006).

\section{RESULTS}

The eight ISSR primers selected produced 79 bands with $96.2 \%$ polymorphism (polymorphism criterion of $95 \%$ ). The mean number of loci per primer was 9.4. The primer UBC835 generated the largest number of bands (13), whereas UBC-862 presented the lowest number of fragments (6) (Table 2). The $H_{\mathrm{E}}$ and $H_{\mathrm{O}}$ values in each population ranged from 0.22 to 0.31 (mean $=0.26)$ and 0.25 to 0.33 (mean $=0.27)$, respectively. The Mantel test revealed positive correlation among genetic and geographic distances $(r=0.5462)$, but it was not significant $(r \geq 0$, $P=0.8365)$. A high value of genetic diversity was observed $\left(H_{E}=0.3581\right)$ and assumed HardyWeinberg equilibrium for all populations of $M$. truncata (Table 1). 
Table 2. Identification of selected ISSR primers with their respective sequences, annealing temperature (Ta), and number of loci (bands) produced.

\begin{tabular}{llcc}
\hline Primer & Sequence $\left(5^{\prime}-3^{\prime}\right)$ & Ta $\left({ }^{\circ} \mathrm{C}\right)$ & Number of bands \\
\hline UBC -809 & AGA GAG AGA GAG AGA GG & 53 & 8 \\
UBC -811 & GAG AGA GAG AGA GAG AC & 53 & 12 \\
UBC -812 & GAG AGA GAG AGA GAG AA & 53 & 11 \\
UBC -835 & AGA GAG AGA GAG AGA GYC & 53 & 13 \\
UBC -840 & GAG AGA GAG AGA GAG AYT & 53 & 10 \\
UBC -842 & GAG AGA GAG AGA GAG AYG & 53 & 9 \\
UBC -862 & AGC AGC AGC AGC AGC AGC & 53 & 6 \\
UBC -864 & ATG ATG ATG ATG ATG ATG & 53 & 10 \\
Total & - & & 79 \\
\hline
\end{tabular}

The UPGMA tree revealed two main clusters (Figure 2a). One group comprised the populations of Jequié, Contendas do Sincorá and Boa Nova, the latter being more genetically distant in relation to others in this cluster, with a bootstrap of $99 \%$. The second cluster was composed of a single population from Boa Vista do Tupim with a bootstrap of $100 \%$. The modal value $k=3$ estimated by Bayesian analysis corroborated the UPGMA results found within populations (Figure 2b).

$\mathbf{a}$
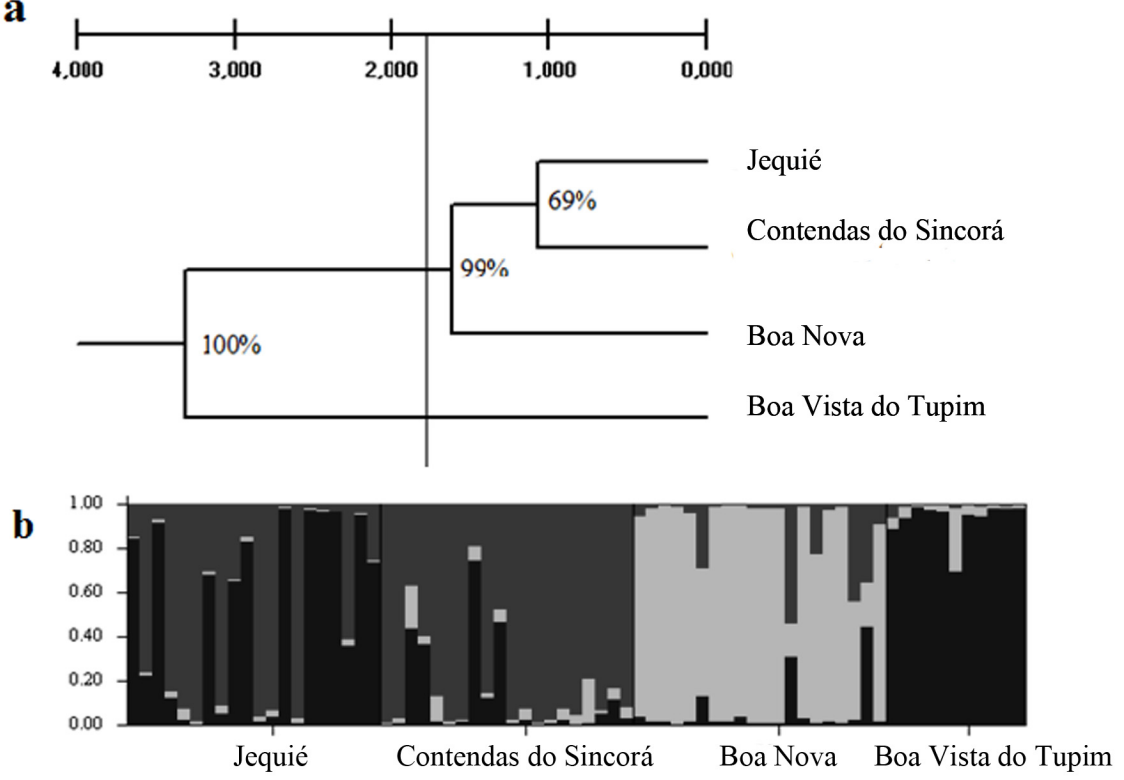

Figure 2. UPGMA dendrogram based on Nei's genetic distance (Nei, 1978) among populations of $M$. truncata in Bahia (a) and genetic relatedness of four populations of $M$. truncata (71 individuals) estimated by STRUCTURE based on ISSR markers (b). The vertical lines in (b) indicate the specimens and colors represent allele frequencies.

\section{DISCUSSION}

Genetic variation is essential to adaptation and evolution of populations inasmuch as information about DNA polymorphism is a key feature to management and conservation of endangered or threatened species (Wang et al., 2012). In spite of the reduced rate of shared alleles among some 
of the studied populations, the specimens of $M$. truncata presented high levels of polymorphism ( $P$ $=96 \%)$ and heterozygosity $\left(H_{\mathrm{E}}=0.3581\right)$ (Table 1$)$ when compared to other congeneric species affected by extractivism. In populations of $M$. ilicifolia, Perecin and Kageyama (2002) identified a genetic diversity of 0.255 . Sahyun (2010) established $H_{E}$ values of 0.197 and $P$ of $79.29 \%$ for populations of M. aquifolium from the state of Paraná, southern Brazil, also using dominant markers.

In spite of the high genetic variability, the fixation index of $0.31(P<0.001)$ detected in M. truncata indicate a high interpopulation differentiation once values $>0.25$ are regarded as evidence of accentuated genetic differences among populations (Wright, 1951). Such structuring in populations of $M$. truncata might be related to the increased exploitation of this natural resource, leading to isolation of populations and restriction to gene flow. This process could be responsible for genetic divergence, particularly noticeable between samples from Boa Nova and Boa Vista do Tupim. By reducing gene flow among populations, inbreeding becomes higher, thus favoring increased fixation index values and population structure. Eventually, this process might determine losses of genetic diversity, which seems to be relatively unaffected so far.

Nonetheless, AMOVA showed that $68 \%$ of genetic variation occurs within populations, which suggests gene flow is still present for at least some populations (Table 3). This is the case with samples from Jequié and Contendas do Sincorá in which their lack of structure suggests they might represent a single population. Most likely, dispersal by birds plays a key role in gene flow between both localities since Contendas do Sincorá seems to be a refuge to dispersers of several plant species. This type of dispersal might encompass a large geographic distance, which allows allele exchange, thereby determining increased intrapopulation variation and lower divergence among localities by gene flow. Indeed, gene flow rates related to dispersal by native animal species and by man can potentially lead to homogenization among populations (Ribeiro et al., 2010), differently than observed with the Mantel test. Both UPGMA and Bayesian analyses revealed congruent population structure patterns. Two main clusters were formed, suggesting alleles are more significantly shared by samples from Jequié and Contendas do Sincorá (Figure 2a), and less frequently between populations of Jequié and Boa Vista do Tupim, which represent two distinguishable genetic pools. Similarly to samples from Boa Vista do Tupim, the population from Boa Nova (Figure 2b), is also genetically distinguished from others, suggesting restraints to gene flow in agreement with the three genetic groups $k=3$ indicated by Bayesian analysis.

Table 3. Analysis of molecular variance (AMOVA) of ISSR markers in samples of Maytenus truncata from Bahia.

\begin{tabular}{lccc}
\hline Source of variation & \% variation & $F$ statistic & $P$ value \\
\hline Among localities & 32 & $\Phi_{\mathrm{ST}}=0.31$ & $<0.001$ \\
Within localities & 68 & & \\
\hline
\end{tabular}

Therefore, the effects of intensive extractivism of $M$. truncata have not yet affected genetic diversity of populations since high rates of polymorphism and heterozygosity were observed, and were even higher than those reported for other exploited plant species used in popular medicine. On the other hand, isolation of populations with formation of distinct genetic groups was detected in this study, probably caused by human activities such as deforestation and habitat fragmentation associated with extraction of native specimens over the last several decades. On a long-term basis, the effects of reduced gene flow and consequent inbreeding will eventually decrease the genetic variation and jeopardize the adaptation and maintenance of native populations, which could drive the species into an extinction vortex (Ribeiro et al., 2010). 
In conclusion, this study shows that despite high genetic diversity of $M$. truncata, there is an accentuated population structure probably related to fragmentation of caatinga and increased extractivism. Thus, more attention should be paid to the sustainable exploitation of this species by local communities that depend on extraction of $M$. truncata for survival. Additionally, ex situ propagation of this species in culture systems should be explored in order to preserve this important natural resource.

\section{Conflicts of interest}

The authors declare no conflict of interest.

\section{ACKNOWLEDGMENTS}

We are grateful to Fundação de Amparo a Pesquisa da Bahia (FAPESB) for the financial support, Universidade Estadual do Sudoeste da Bahia for the research facilities, to Herbarium of the UESB - HUESB and Elder Assis Miranda and Alberto Leôncio Vasconcelos for their assistance with sample collection.

\section{REFERENCES}

Almeida MT, Ríos-Luci C, Padrón JM and Palermo JA (2010). Antiproliferative terpenoids and alkaloids from the roots of Maytenus vitis-idaea and Maytenus spinosa. Phytochemistry 71: 1741-1748.

Ersts PJ (2006) Geographic Distance Matrix Generator. Version 1.2.3. Available at [http://biodiversityinformatics.amnh.org/ open_source/gdmg].

Evanno G, Regnaut S and Goudet J (2005). Detecting the number of clusters of individuals using the software STRUCTURE: a simulation study. Mol. Ecol. 14: 2611-2620.

Excoffier L, Laval G and Schneider S. (2007). Arlequin: An integrated software package for population genetics data analysis, Verson 3.0. Evol. Bioinform. Online 1: 47-50.

Faleiro FG (2007). Marcadores genético-moleculares aplicados a programas de conservação e uso de recursos genéticos. Embrapa Cerrados, Planaltina.

Falush D, Stephens M and Pritchard JK (2007). Inference of population structure using multilocus genotype data: dominant markers and null alleles. Mol. Ecol. Notes 7: 574-578.

Fonseca APND, Silva GDF, Carvalho JJ, Salazar GCM et al. (2007). Estudo fitoquímico do decocto das folhas de Maytenus truncata Reissek e avaliação das atividades antinoceotiva, antiedematogênica e antiulcerogênica de extratos do decocto. Quim Nova 4: 842-847.

Jensen JL, Bohonak AJ and Kelley ST (2005). Isolation by distance, web service. BMC Genet. 6: 13.

León L, López MR and Moujir L (2010). Antibacterial properties of zeylasterone, a triterpenoid isolated from Maytenus blepharodes, against Staphylococcus aureus. Microbiol. Res. 165: 617-626.

Liu B and Wendel JF (2001). Intersimple sequence repeat (ISSR) polymorphisms as a genetic marker system in cotton. Mol. Ecol. Notes 1: 205-208.

Martucciello S, Balestrieri ML, Felice F, Estevam CS, et al. (2010). Effects of triterpene derivatives from Maytenus rigida on VEGF-induced Kaposi's sarcoma cell proliferation. Chem. Biol. Interact. 183: 450-454.

Miller MP (1997). Tools for population genetics analyses (TFPGA). Version 1.3: A Windows program for the analysis of allozyme and molecular population genetic data. Available at [http://herb.bio.nau.edulmiller/tfpga.htm].

Momtaz S, Hussein AA, Ostad SN, Abdollahi M, et al. (2013). Growth inhibition and induction of apoptosis in human cancerous HeLa cells by Maytenus procumbens. Food Chem. Toxicol. 51: 38-45.

Morita H, Hirasawa Y, Muto A, Yoshida T, et al. (2008). Antimitotic quinoid triterpenes from Maytenus chuchuhuasca. Bioorg. Med. Chem. Lett. 18: 1050-1052.

Negri MLS, Possamai JC and Nakashima T (2009). Atividade antioxidante das folhas de espinheira-santa - Maytenus ilicifolia Mart. ex Reiss., secas em diferentes temperaturas. Rev. Bras. Farmacogn. 19: 553-556.

Perecin MB and Kageyama PY (2002). Variabilidade enzimática em populações naturais de espinheira - santa Maytenus 
aquifolia Mart e Maytenus ilicifolia Mart ex Reiss e suas implicações para o manejo da conservação. Rev. Bras. Pl. Med. 4: 80-90.

Ribeiro MV, Bianchi VJ, Rodrigues ICS, Mariot MP et al. (2010). Diversidade genética entre acessos de espinheira-santa (Maytenus ilicifolia Mart. ex Reis.) coletados no estado do Rio Grande do Sul, Brasil. Rev. Bras. Plantas Med. 12: 443-451.

Sahyun AS, Ruas EA, Ruas CF, Medri C, et al. (2010). Genetic variability of three natural populations of Maytenus aquifolium (Celastraceae) from Telêmaco Borba, Paraná, Brazil. Braz. Arch. Biol. Technol. 5: 1037-1042.

Silva SN, Pereira DG, Waldschmitd AM and Corrêa RX (2008). Otimização de Protocolo para Extração de DNA de Maytenus truncata Reis. Caatinga 21: 100-103.

Steenbock W and Reis MS (2004). Manejo de populações naturais de espinheira santa. In: Conservação e uso sustentável de plantas medicinais e aromáticas: Maytenus spp., Espinheira-santa (Reis MS and Silva SR eds.). Ibama, Brasil, 145-161.

Wang X, Yang R, Feng S, Hou X, et al. (2012). Genetic variation in Rheum palmatum and Rheum tanguticum (Polygonaceae), two medicinally and endemic species in China using ISSR markers. PLoS One 7: e51667.

Wright S (1951). The genetical structure of populations. Ann. Eugen. 15: 323354

Wu FQ, Shen SK, Zhang XJ, Wang YH, et al. (2014). Genetic diversity and population structure of an extremely endangered species: the world's largest Rhododendron. AoB Plants 7: 82.

Zietkiewicz E, Rafalski A and Labuda D (1994). Genome fingerprinting by simple sequence repeat (SSR)-anchored polymerase chain reaction amplification. Genomics 20: 176-183. 